\title{
Contamination and health risk assessment of heavy metals in road dust in Bayan Obo Mining Region in Inner Mongolia, North China
}

\author{
LI Kexin, "LIANG Tao, "WANG Lingqing, YANG Zhiping
}

Key Laboratory of Land Surface Pattern and Simulation, Institute of Geographic Sciences and Natural Resources Research, CAS, Beijing 100101, China

Abstract: The objective of this study was to investigate the concentration and spatial distribution patterns of 9 potentially toxic heavy metal elements ( $\mathrm{As}, \mathrm{Cd}, \mathrm{Co}, \mathrm{Cr}, \mathrm{Pb}, \mathrm{Cu}, \mathrm{Zn}$, $\mathrm{Mn}$, and $\mathrm{Ni}$ ) in road dust in the Bayan Obo Mining Region in Inner Mongolia, China. Contamination levels were evaluated using the geoaccumulation index and the enrichment factor. Human health risks for each heavy metal element were assessed using a human exposure model. Results showed that the dust contained significantly elevated heavy metal elements concentrations compared with the background soil. The spatial distribution pattern of all tested metals except for As coincided with the locations of industrial areas while the spatial distribution of As was associated with domestic sources. The contamination evaluation indicated that $\mathrm{Cd}, \mathrm{Pb}$, and $\mathrm{Mn}$ in road dust mainly originated from anthropogenic sources with a rating of "heavily polluted" to "extremely polluted," whereas the remaining metals originated from both natural and anthropogenic sources with a level of "moderately polluted". The noncancer health risk assessment showed that ingestion was the primary exposure route for all metals in the road dust and that $\mathrm{Mn}, \mathrm{Cr}, \mathrm{Pb}$, and $\mathrm{As}$ were the main contributors to non-cancer risks in both children and adults. Higher $\mathrm{HI}$ values were calculated for children $(H I=1.89)$, indicating that children will likely experience higher health risks compared with adults $(\mathrm{HI}=0.23)$. The cancer risk assessment showed that $\mathrm{Cr}$ was the main contributor, with cancer risks which were 2-3 orders of magnitude higher than those for other metals. Taken in concert, the non-cancer risks posed by all studied heavy metal elements and the cancer risks posed by As, Co, Cr, Cd, and Ni to both children and adults in Bayan Obo Mining Region fell within the acceptable range.

Keywords: road dust; heavy metal elements; contamination assessment; health risk assessment; Bayan Obo Mining Region

J. Geogr. Sci. 2015, 25(12): 1439-1451

DOI: $10.1007 /$ s11442-015-1244-1

\section{Introduction}

Road dust is comprised of solid particles which accumulate on impervious, hard road surfaces, such as cement and sidewalks in urban areas (Liu et al., 2014). Road dust plays an active role as a "sink and source" of pollutants due to enhanced levels of metals and other pollutants and frequent interactions of dust with the atmosphere and other mediums through resuspension and deposition of dust particles (Moreno et al., 2013). Therefore, road dust can contribute significantly to environmental pollution in urban areas and is considered an indicator of heavy

Received: 2015-03-04 Accepted: 2015-05-10

Foundation: National Natural Scientific Foundation of China, No.41571473, No.41401591

Author: Li Kexin, PhD, specialized in air pollution and human health assessment. E-mail: mouselkx_cindy@126.com

*Corresponding author: Liang Tao, Professor, E-mail: liangt@igsnrr.ac.cn; Wang Lingqing, E-mail: wanglq@igsnrr.ac.cn 
metal contamination from atmospheric deposition (Zheng et al., 2010a). Moreover, heavy metal elements in road dust are known to easily enter the human body through ingestion, inhalation, and dermal contact (Cook et al., 2005). The adverse effects on human health from exposure to heavy metal elements have been well-documented (Valko et al., 2006; Zheng et al., 2006; Sun et al., 2010), necessitating a thorough determination of the health risks of road dust containing to local residents (Shi et al., 2008).

Several prior studies have evaluated the concentration, distribution, pollution potential, and health risks of heavy metals in road dust (Zheng et al., 2010a; Apeagyei et al., 2011). However, most previous research focused on road dust in capital cities or mega-cities which were characterized by dense traffic and overpopulation. Small regions affected mainly by mining activities have received relatively limited attention. Mining activities are notorious for their adverse impacts on the environment (Wang et al., 2008). Large quantities of dust laden with high levels of heavy metals can be released into the air and deposited as road dust as a result of mining operations including crushing, grinding, excavating, smelting, and refining (Csavina et al., 2012). Thus, in comparison with mega-cities or capital cities, the environmental and human health risks associated with road dust metals in mining regions requires further investigation.

Bayan Obo is a mining town in western Inner Mongolia. Mining activities were in operation for 80 years before the discovery of iron minerals in 1927 and rare earth elements (REE) minerals in 1936. Larger-scale mining has led to soil pollution with heavy metals in Bayan Obo (Guo et al., 2011; Si et al., 2015). However, the contamination characteristics of heavy metals in road dust in Bayan Obo, as well as the association between dust-borne metallic elements and their adverse human health impacts, are not well understood.

In an effort to supplement previous research and obtain more information regarding road dust pollution in Bayan Obo, the objectives of this study were to 1) investigate the mass concentration of heavy metal components of road dust collected in Bayan Obo and analyze their spatial variation; 2) evaluate the contamination levels of these metals using the geoaccumulation index $\left(\mathrm{I}_{\text {geo }}\right)$ and enrichment factor $(\mathrm{EF})$; and 3 ) develop a quantitative estimation of the non-carcinogenic and carcinogenic risks of heavy metals in road dust to local residents.

\section{Materials and methods}

\subsection{Site description}

Bayan Obo Mining Region (hereafter Bayan Obo for short) $\left(41^{\circ} 46^{\prime} 58^{\prime \prime} \mathrm{N}, 109^{\circ} 58^{\prime} 25^{\prime \prime} \mathrm{E}\right)$ is considered the largest known (REE)-Fe-Nb deposit. Located in the west of Inner Mongolia, Bayan Obo contains large reserves on iron, niobium, and REE. Containing 1.4 billion tons of iron, 1 million tons of $\mathrm{Nb}_{2} \mathrm{O}_{5}$, and more than 40 million tons of REE minerals (70\% of global REE storage) (Wu, 2008), Bayan Obo contributes $45 \%$ of worldwide REE production (Drew et al., 1990). The main minerals present are bastnasite, monazite, and RE-Nb minerals such as aeschynite, felgusonite, and columbite. The mining region is comprised of 3 ore zones: the Main Orebody, the East Orebody, and the West Orebody. The region is $48 \mathrm{~km}^{2}$ in area, $18 \mathrm{~km}$ in length from east to west, and $3 \mathrm{~km}$ in width from north to south. The Main Orebody and the East Orebody contain $5.41 \%$ and $5.18 \%$ rare earth oxides (REOs), respectively, while the 
West Orebody is still in the exploitation process. Iron and REE minerals are currently extracted at a rate of 15,000 tons per day from the Main and East Orebodies. The raw minerals are transported through railways to Baotou city for reprocessing, while the 8 tons of tailing products produced each year are disposed of freely in open pits (Wang et al., 2014).

Bayan Obo is characterized by a cold semi-arid climate with a mean annual temperature of $7.2^{\circ} \mathrm{C}$. Prevailing winds are southeast towards the residential area with an average wind speed of $1.2 \mathrm{~m} \cdot \mathrm{sec}^{-1}$. Nearly 30,000 people live in the residential area located in the south of the ore body, most of them work for the mining industry. The dry climate and strong winds allow for extensive dispersal of the dust in mining sites, especially in the downwind direction towards the residential areas. The vast grasslands in the areas cannot effectively block dust dispersion due to intense winds.

\subsection{Sample collection}

A total of 23 points distributed in the main residential area were selected as road dust sampling sites in Bayan Obo Mining Region (Figure 1), including sites near the mine. There are no commercial activities in the Bayan Obo region. At each sampling site, approximately $200 \mathrm{~g}$ of composite road dust from 3-5 sub-sampling sites were collected in April 2014 from impervious surfaces (road, pavement and gutter) using a clean polyethylene brush and tray. The exact location of each sampling site was measured by global positioning system (GPS). All road dust samples were stored in self-sealed polyethylene bags, labeled, and transported to the laboratory for analysis.

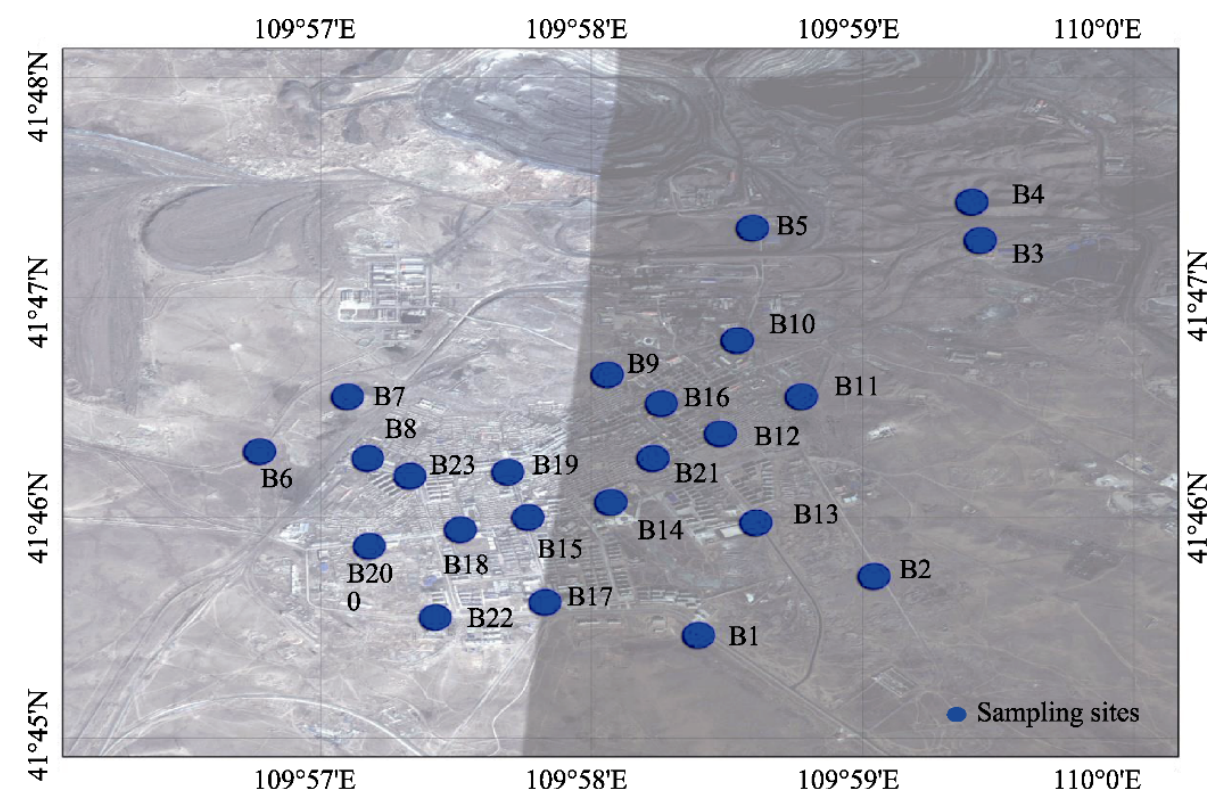

Figure 1 Map of the study area and sampling sites in Bayan Obo Mining Region (April 2014)

\subsection{Sample processing}

All samples were air-dried naturally for approximately 15 days, sieved through a $2.0 \mathrm{~mm}$ mesh nylon sieve to remove small stones and debris, and then carefully resieved through a 0.1 
$\mathrm{mm}$ sieve. Prior to determination of heavy metals concentrations, sieved dust samples were ground and then a $0.5 \mathrm{~g}$ milled dust sample was digested in a mixture of $\mathrm{HNO}_{3}, \mathrm{HClO}_{4}$ and $\mathrm{HF}$ solution by heating to obtain ca. $0.5 \mathrm{ml}$ of colorless solution. After cooling, the solution was transferred to a test tube and then diluted to $25 \mathrm{~mL}$ with deionized water. Concentrations of $\mathrm{Cr}$, $\mathrm{Cu}, \mathrm{Zn}, \mathrm{Pb}$, and $\mathrm{Ni}$ were determined by inductively coupled plasma optical emission spectroscopy (ICP-OES, Optima 5300 DV, Perkin Elmer) and concentrations of Cd and Co were analyzed by inductively coupled plasma mass spectrometry (ICP-MS, ELAN DRC-e, Perkin Elmer SCIEX). Each measurement was conducted in duplicate. National reference samples, replicates, and blanks were used to ensure accuracy of the results. The relative errors of all measurements were less than $5 \%$ on average. To prevent potential contamination of the samples, all chemical treatments were performed in an ultra-clean laboratory, and all reagents were at high purity grade.

\subsection{Contamination assessment methodology}

\subsubsection{Geoaccumulation index}

The geoaccumulation index $\left(\mathrm{I}_{\mathrm{geo}}\right)$ developed by Müller (1969) was previously adopted to assess metal pollution (Wei et al., 2009; Lu et al., 2009; Fu et al., 2012). In this study, Igeo was used to identify whether the road dust in Bayan Obo were polluted by heavy metals and quantify the degree of the contamination. $\mathrm{I}_{\text {geo }}$ was calculated by:

$$
I_{\text {geo }}=\log _{2}\left(C_{n} / 1.5 B_{n}\right)
$$

where $C_{n}$ is the concentration of the metal in the road dust, $B_{n}$ is the background level of metals in soils of Inner Mongolia (Gao et al., 2007; Xu and Tao, 2004), and the factor 1.5 is a constant value to account for possible variations in background values (Wei et al., 2009). Based on $\mathrm{I}_{\text {geo }}$ values, the sites were categorized into seven classes (Table 1) (Müller, 1969).

Table 1 The classification of contamination levels based on the $I_{\text {geo }}$ values

\begin{tabular}{ll}
\hline \multicolumn{1}{c}{$\mathrm{I}_{\text {geo }}$ value } & \multicolumn{1}{c}{ Class } \\
\hline $\mathrm{I}_{\text {geo }} \leqslant 0$ & Unpolluted \\
$0<\mathrm{I}_{\mathrm{geo}} \leqslant 1$ & Unpolluted/Moderately polluted \\
$1<\mathrm{I}_{\mathrm{geo}} \leqslant 2$ & Moderately polluted \\
$2<\mathrm{I}_{\mathrm{geo}} \leqslant 3$ & Moderately polluted/Strongly polluted \\
$3<\mathrm{I}_{\mathrm{geo}} \leqslant 4$ & Strongly polluted \\
$4<\mathrm{I}_{\mathrm{geo}} \leqslant 5$ & Strongly polluted/Extremely polluted \\
$\mathrm{I}_{\mathrm{geo}}>5$ & Extremely polluted \\
\hline
\end{tabular}

\subsubsection{Enrichment factor}

Enrichment factor (EF) has been widely used to differentiate anthropogenic and natural sources of trace elements in soils (Lu et al., 2009). EF is defined as:

$$
\mathrm{EF}=\left(\frac{\mathrm{C}_{\mathrm{n}}}{\mathrm{R}}\right)_{\text {dust }} /\left(\frac{\mathrm{C}_{\mathrm{n}}}{\mathrm{R}}\right)_{\text {background }}
$$

where $C_{n}$ and $R$ are concentrations of the metal and reference element, respectively, in the road dust or the background soil. In this study, Al was selected as the reference material. A value of EF close to 1 indicates a crustal origin, whereas those EF values $>10$ indicates a noncrustal source (Wang et al., 2014). 


\subsection{Health risk assessment model}

\subsubsection{Exposed dose}

In this study, the risk assessment model developed by the Environmental Protection Agency of the United States (US EPA) was used to evaluate the health risks posed by heavy metals in road dust. Local residents were divided into adults and children and the following exposure categories were used: (1) adults and children through mouth and nose; 2) ingestion of dust particles through mouth; and 3) dermal contact with dust through exposed skin. According to the human health evaluation manual (Part A) and supplemental guidance for dermal risk assessment (Part E) (EPA, 1989; 2004), the daily intake dose (D) of a pollutant through each pathway can be evaluated:

$$
\begin{gathered}
\mathrm{D}_{\text {ing }}=\frac{\mathrm{C} \times \mathrm{IngR} \times \mathrm{EF} \times \mathrm{ED} \times \mathrm{CF}}{\mathrm{BW} \times \mathrm{AT}} \\
\mathrm{D}_{\text {inh }}=\frac{\mathrm{C} \times \mathrm{InhR} \times \mathrm{EF} \times \mathrm{ED}}{\mathrm{BW} \times \mathrm{AT} \times \mathrm{PEF}} \\
\mathrm{D}_{\text {dermal }}=\frac{\mathrm{C} \times \mathrm{SA} \times \mathrm{SL} \times \mathrm{ABS} \times \mathrm{EF} \times \mathrm{ED} \times \mathrm{CF}}{\mathrm{BW} \times \mathrm{AT}}
\end{gathered}
$$

According to the classification list developed by the International Agency for Research on Cancer (IARC), four carcinogenic metals ( $\mathrm{As}, \mathrm{Cd}, \mathrm{Cr}$ and $\mathrm{Ni}$ ), and one possible carcinogen Co (Group 2B) were investigated for their carcinogenic risks (IARC, 2014). The life time average daily dose for these five metals was calculated by:

$$
\mathrm{LADD}=\frac{\mathrm{C} \times \mathrm{EF}}{\mathrm{AT} \times \mathrm{PEF}} \times\left(\frac{\text { InhR child } \times \text { EDchild }}{\text { BW child }}+\frac{\text { InhRadult } \times \text { EDadult }}{\text { BWadult }}\right)
$$

where $C$ is the upper limit of the $95 \%$ confidence interval for the mean ( $95 \%$ UCL), which is considered as a conservative estimate of the "reasonable maximum exposure" (EPA, 1992). Since the concentrations of most metals in the road dust samples followed an approximate log-normal distribution, the 95\% UCL in this study was calculated using previously described methods (Zheng et al., 2010a; Zheng et al., 2010b). The other exposure factors for these models are shown in Table 2.

\subsubsection{Risk characterization}

For non-carcinogenic risks, Hazard quotient (HQ) was used to assess the non-carcinogenic risks posed by metals in road dust.

$$
\mathrm{HQ}=\mathrm{D} / \mathrm{RfD}
$$

where RfD is the corresponding reference dose. An $\mathrm{HQ}<1$ indicates no adverse health effects, while $\mathrm{HQ}>1$ indicates that adverse health effects are likely to occur.

The hazard index (HI) is equal to the sum of HQs and is used to represent the total potential non-carcinogenic risks of different pollutants via three exposure routes described previously. An $\mathrm{HI}<1$ indicates that there is no significant risk of non-carcinogenic effects. If $\mathrm{HI}>1$, then a noncarcinogenic effect is likely to exist (EPA, 1989).

In the case of carcinogenic risks, the life time cancer risk can be estimated by: 


\section{$\mathrm{R}=\mathrm{LADD} / \mathrm{SF}$}

where SF is the corresponding slope factor. Any cancer risk in the range of $10^{-6}-10^{-4}$ is considered acceptable by the US EPA (1989). The RfD and SF values of all investigated metals (Ferreira-Baptista and De Miguel, 2005; Zheng et al., 2010) are presented in Tables 7 and 8 .

Table 2 Exposure factors

\begin{tabular}{|c|c|c|c|c|c|}
\hline \multirow{2}{*}{ Factor } & \multirow{2}{*}{ Definition } & \multicolumn{2}{|c|}{ Value } & \multirow{2}{*}{ Unit } & \multirow{2}{*}{ Reference } \\
\hline & & Adults & Children & & \\
\hline BW & Average body weight & 70 & 15 & $\mathrm{~kg}$ & EPA, 1989 \\
\hline IngR & Ingestion rate & 100 & 200 & $\mathrm{mg} \cdot$ day $^{-1}$ & EPA, 1989 \\
\hline InhR & Inhalation rate & 20 & 7.6 & $\mathrm{~m}^{3} \cdot \mathrm{day}^{-1}$ & $\begin{array}{l}\text { Zheng et al. } \\
2010 \mathrm{a}\end{array}$ \\
\hline PEF & Particle emission factor & \multicolumn{2}{|c|}{$1.36 \times 10^{9}$} & $\mathrm{~m}^{3} \cdot \mathrm{kg}^{-1}$ & EPA, 2001 \\
\hline SA & $\begin{array}{l}\text { Surface areas of the skin that } \\
\text { contacts the airborne particulates }\end{array}$ & 5700 & 2800 & $\mathrm{~cm}^{-2}$ & EPA, 2004 \\
\hline SL & Skin adherence factor & 0.07 & 0.2 & $\mathrm{mg} \cdot \mathrm{m}^{-3}$ & \\
\hline $\mathrm{EF}$ & Exposure frequency & 180 & 180 & days $\cdot$ year $^{-1}$ & $\begin{array}{l}\text { Zheng et al. } \\
2010 \mathrm{a}\end{array}$ \\
\hline ED & Exposure duration & 24 & 6 & years & \\
\hline ET & Exposure time & \multicolumn{2}{|c|}{24} & hours $\cdot$ day $^{-1}$ & \\
\hline AT (non-cancer risk) & Averaging time & \multicolumn{2}{|c|}{$\mathrm{ED} \times 365$} & days & \\
\hline AT (cancer risk) & Averaging time & \multicolumn{2}{|c|}{$70 \times 365$} & days & \\
\hline ABS & Dermal absorption factor & \multicolumn{2}{|c|}{$\begin{array}{c}0.03 \text { for As, } \\
0.001 \text { for other metals }\end{array}$} & - & EPA,2004 \\
\hline $\mathrm{CF}$ & Conversion factor & \multicolumn{2}{|c|}{$1 \times 10^{-6}$} & $\mathrm{~kg} \cdot \mathrm{mg}^{-1}$ & \\
\hline
\end{tabular}

Table 3 The concentrations of heavy metals in road dust collected in Bayan Obo (April 2014, $\mathrm{mg} \cdot \mathrm{kg}^{-1}$ )

\begin{tabular}{crrrrrrr}
\hline Concentration & Maximum & Minimum & Mean & $\begin{array}{c}\text { Geometric } \\
\text { mean }\end{array}$ & Median & S.D. & $\begin{array}{c}\text { Inner } \\
\text { Mongolia B. }\end{array}$ \\
\hline $\mathrm{Cd}$ & 4.63 & 1.21 & 2.20 & 2.05 & 1.83 & 0.90 & 0.037 \\
$\mathrm{Co}$ & 41.27 & 20.65 & 26.94 & 26.62 & 25.74 & 4.49 & 9.0 \\
$\mathrm{Cr}$ & 260.80 & 85.09 & 141.24 & 136.76 & 139.60 & 38.46 & 35.7 \\
$\mathrm{Cu}$ & 51.09 & 20.49 & 36.39 & 35.75 & 36.36 & 6.79 & 12.7 \\
$\mathrm{~Pb}$ & 526.70 & 88.04 & 183.93 & 167.51 & 160.50 & 95.41 & 13.5 \\
$\mathrm{Zn}$ & 729.00 & 192.00 & 299.37 & 283.92 & 261.80 & 117.51 & 47.5 \\
$\mathrm{As}$ & 19.46 & 8.01 & 12.02 & 11.78 & 11.49 & 2.57 & 6.1 \\
$\mathrm{Ni}$ & 49.82 & 24.96 & 31.25 & 30.85 & 29.41 & 5.52 & 16.6 \\
$\mathrm{Mn}$ & 7956.00 & 1575.00 & 3407.30 & 3206.43 & 3172.00 & 1349.94 & 434.3 \\
\hline
\end{tabular}

\section{Results}

\subsection{Heavy metals contents in road dust}

The descriptive statistics related to heavy metal content of dust in the Bayan Obo region are 
listed in Table 3. The background values of the metals in soils of Inner Mongolia are also shown in Table 3. The concentrations of 9 metals varied widely in this region and followed the order of $\mathrm{Mn}>\mathrm{Zn}>>\mathrm{Pb}>\mathrm{Cr}>\mathrm{Cu}>\mathrm{Ni}>\mathrm{Co}>\mathrm{As}>\mathrm{Cd}$. All road dust showed contained elevated concentrations of heavy metals in comparison with those of Inner Mongolia background average concentrations (Xu and Tao, 2004; Gao et al., 2007). This was particularly true for $\mathrm{Cd}$, which exceeded the background value 60 -fold.

The mean heavy metal content was compared to the data collected from other cities or regions reported in previous studies (Table 4). These results indicated that the road dust in residential areas of Bayan Obo contains considerably higher concentrations of $\mathrm{Cd}$, $\mathrm{Co}$, and $\mathrm{Mn}$, and lower levels of in $\mathrm{Cu}, \mathrm{Zn}$ and $\mathrm{Ni}$ compared with other cities, except for $\mathrm{Ni}$ in Hangzhou (Zhang and Wang, 2009). The concentration of $\mathrm{Cr}$ was close to that measured in Shanghai (Shi et al., 2008), Nanjing (Liu et al., 2014), and Baoji (Lu et al., 2009), where urban environments were heavily affected by human activities. Additionally, the $\mathrm{Pb}$ content in Bayan Obo, which exceeded that measured in Urumqi (Wei et al., 2009) and Nanjing (Liu et al., 2014), was still detected at a relatively low level compared with other industrial and developed cities.

Table 4 The average concentrations of heavy metals in road dust in different areas $\left(\mathrm{mg} \cdot \mathrm{kg}^{-1}\right)$

\begin{tabular}{lcccccccccc}
\hline Concentration & $\mathrm{Cd}$ & $\mathrm{Co}$ & $\mathrm{Cr}$ & $\mathrm{Cu}$ & $\mathrm{Pb}$ & $\mathrm{Zn}$ & $\mathrm{As}$ & $\mathrm{Ni}$ & $\mathrm{Mn}$ & Reference \\
\hline Bayan Obo & 2.20 & 26.94 & 141.24 & 36.39 & 183.93 & 299.37 & 12.02 & 31.25 & 3407.30 & This study \\
Hangzhou & 1.59 & 19.96 & 51.29 & 116.04 & 202.16 & 321.40 & & 25.88 & 509.56 & Zhang and Wang, 2009 \\
Urumqi & 1.17 & 10.97 & 54.28 & 94.54 & 53.53 & 294.47 & & 43.28 & 926.60 & Wei et al., 2009 \\
Shanghai & 1.23 & & 159.30 & 196.80 & 294.90 & 733.80 & & 83.98 & & Shi et al., 2008 \\
Baoji & & 15.90 & 126.70 & 123.17 & 433.20 & 715.30 & 19.80 & 48.80 & 804.20 & Lu et al., 2009 \\
Nanjing & & & 139.0 & 238.0 & 113.0 & 307.0 & & 47.0 & 786.0 & Liu et al., 2014 \\
Inner Mongolia B. & 0.037 & 9.0 & 35.7 & 12.7 & 13.5 & 47.5 & 6.1 & 16.6 & 434.3 & $\begin{array}{l}\text { Xu et al., 2004 } \\
\text { Gao et al., 2007 }\end{array}$ \\
China B. & 0.07 & 11.2 & 53.9 & 20.0 & 23.6 & 67.7 & 11.2 & 23.4 & 482.0 & Xu et al., 2004 \\
\hline
\end{tabular}

\subsection{Spatial distributions of heavy metals in road dust}

The spatial distribution pattern of 9 potentially toxic metals (As, $\mathrm{Cd}, \mathrm{Co}, \mathrm{Cr}, \mathrm{Pb}, \mathrm{Cu}, \mathrm{Zn}, \mathrm{Mn}$ and $\mathrm{Ni}$ ) in road dust in Bayan Obo is presented in Figure 2. $\mathrm{Cd}, \mathrm{Cr}, \mathrm{Co}, \mathrm{Pb}, \mathrm{Cu}, \mathrm{Mn}, \mathrm{Ni}$, and $\mathrm{Zn}$ show spatial distribution patterns which coincide with the locations of industrial areas. The concentrations of those eight metals were higher near tailing ponds and ore bodies in the west and north, and in good agreement with the predominated wind direction. These results indicated that heavy metals (except for As) likely originate from industrial sources in the study region. The spatial distribution pattern of As was very different from those of the other tested metals. The hot-spot areas of As were mainly associated with residential areas located in the south of the study region, suggesting that As contamination may be primarily associated with domestic pollution sources. Several restaurants in these areas were used by residents for ceremonies and celebrations which often included the use of large amounts of fireworks. Additionally, residents in Bayan Obo region still cook by the coal-fired style, which can result in significant arsenic emissions (Zhang et al., 2002). 


\subsection{Contamination assessment results}

High "absolute" values of metals are not necessarily positively correlated to higher metal contamination levels due to variations in geochemical background levels, land use patterns, and human activities among different cities. Therefore, the geoaccumulation index was used to assess the contamination extent. The average $\mathrm{I}_{\text {geo }}$ values of $\mathrm{As}, \mathrm{Ni}, \mathrm{Cu}$, and $\mathrm{Co}$ fell in the range of $0-1$ (Figure 3), indicating that the road dust in Bayan Obo residential areas were polluted or moderately polluted by these four metals. The average $\mathrm{I}_{\text {geo }}$ value of $\mathrm{Cr}$ and Zn were 1.35 and 1.99, respectively, placing those two metals into the class of moderately polluted. The average $I_{\text {geo }}$ value for $\mathrm{Mn}$ (2.30) resulted in a moderately to heavily polluted determination, while the average index of $\mathrm{Pb}$ (slightly higher than 3 ), pointed to a heavy contamination. Cd contamination resulted in the highest $\mathrm{I}_{\text {geo }}$ value (5.21), suggesting that the road dust was extremely polluted by $\mathrm{Cd}$ in Bayan Obo residential areas. Take in concert, the contamination levels of the 9 studied heavy metals were in the order of $\mathrm{Cd}>\mathrm{Pb}>\mathrm{Mn}>\mathrm{Zn}>\mathrm{Cr}>\mathrm{Co}>\mathrm{Cu}>\mathrm{As}>\mathrm{Ni}$.
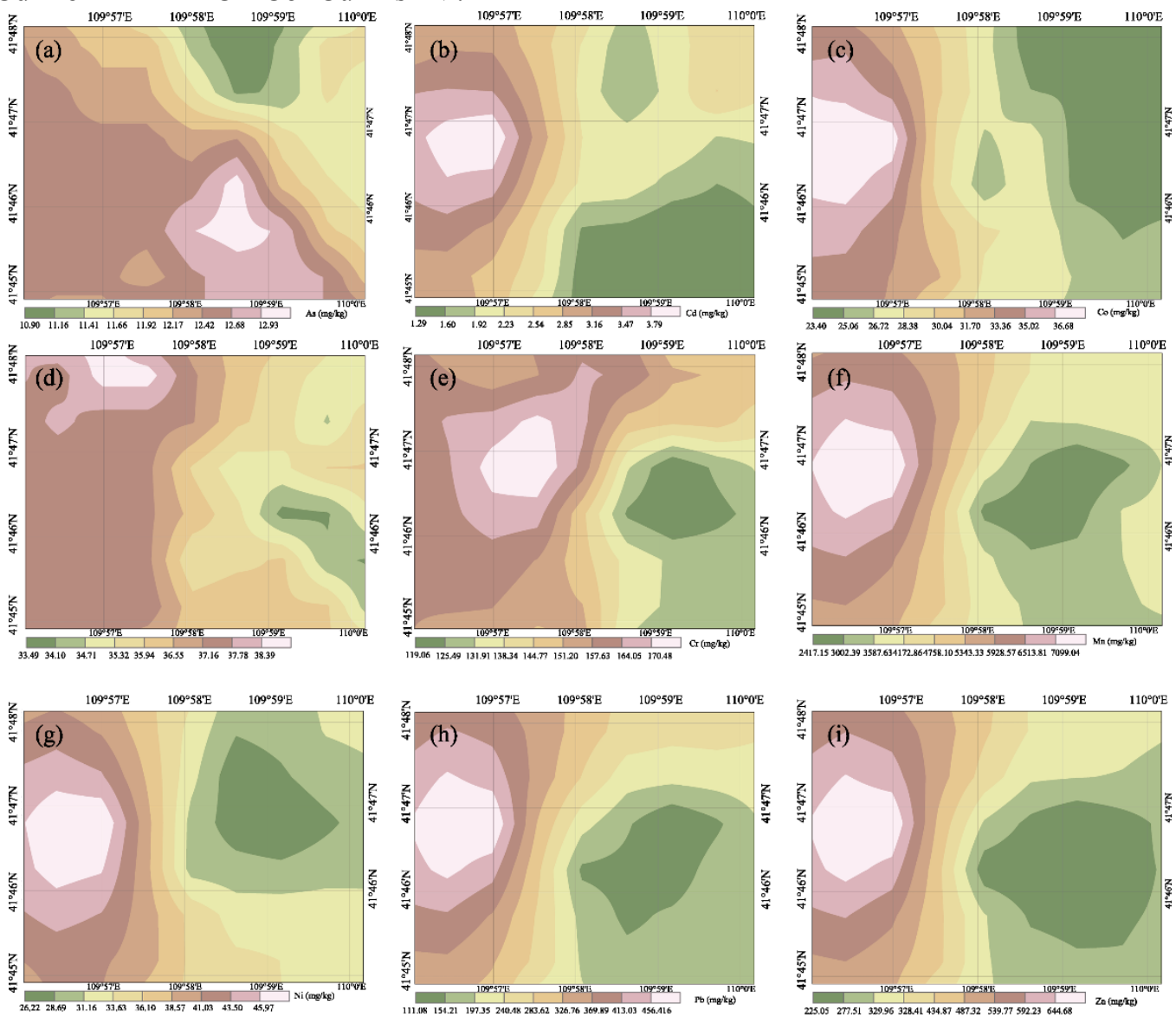

Figure 2 The spatial distribution of heavy metal elements (As, $\mathrm{Cd}, \mathrm{Co}, \mathrm{Cr}, \mathrm{Pb}, \mathrm{Cu}, \mathrm{Zn}, \mathrm{Mn}$ and $\mathrm{Ni}$ ) in road dust in Bayan Obo (April 2014) 


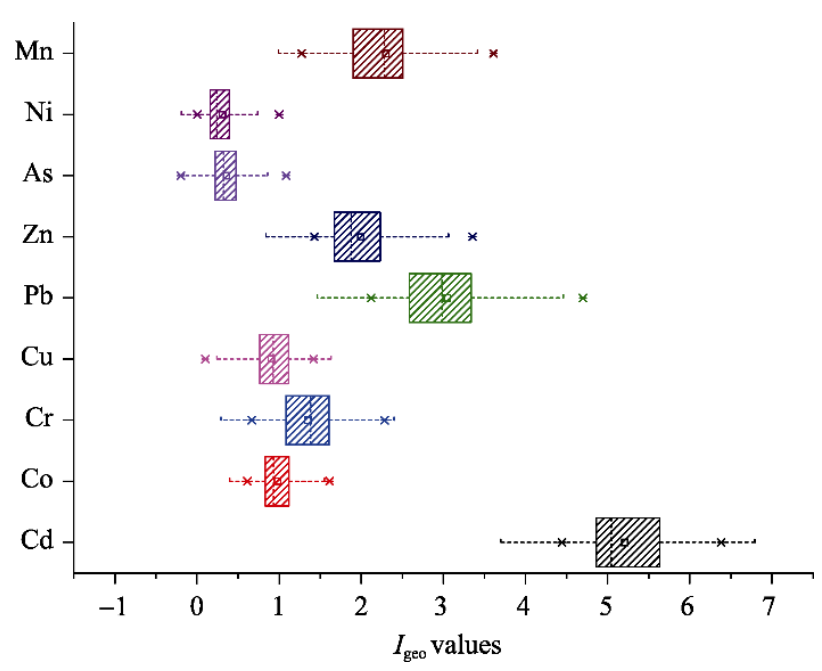

Figure 3 The $I_{\text {geo }}$ value of heavy metals in road dust in Bayan Obo (April 2014)

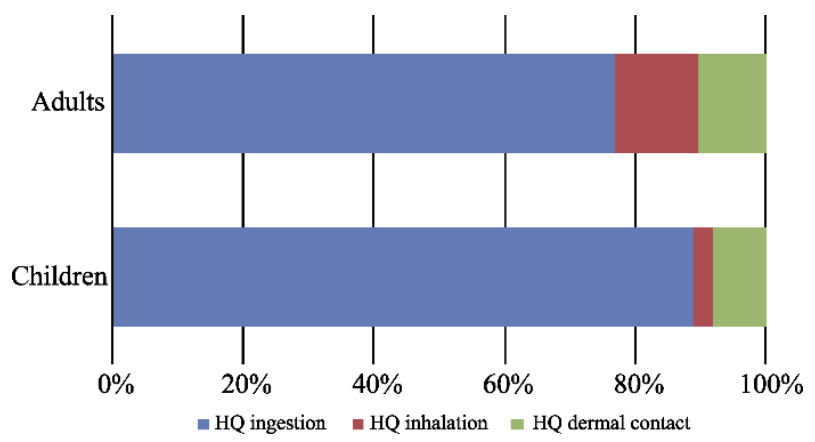

Figure 4 Non-carcinogenic risk distribution of different exposure ways for children and adults in Bayan Obo (April 2014)

The $I_{\text {geo }}$ values of heavy metals in this study were also compared to results from other cities reported in previous studies. As shown in Table 5, the road dust in residential areas of Bayan Obo was contaminated by $\mathrm{Cr}, \mathrm{Cd}, \mathrm{Pb}, \mathrm{Mn}$, and $\mathrm{Co}$ at higher levels, whereas by $\mathrm{Cu}, \mathrm{As}$, and $\mathrm{Ni}$ was relatively low compared to other cities. Contamination by $\mathrm{Zn}$ was higher compared with cities without industry and overpopulation, such as Hangzhou(Zhang and Wang, 2009) and Urumqi (Wei et al., 2009), but lower than that measured in the heavy industrial city of Baoji (Lu et al., 2009) and developed city of Shanghai (Shi et al., 2008). Despite the low absolute $\mathrm{Pb}$ concentrations, levels of $\mathrm{Pb}$ pollution were still higher than those in other cities and similar with that measured in Baoji (Lu et al., 2009), in which the absolute Pb concentration was 2.36 times higher than that in Bayan Obo.

Table 5 The average $\mathrm{I}_{\text {geo }}$ values of heavy metals in road dust in different areas

\begin{tabular}{cllllllllll}
\hline $\mathrm{I}_{\text {geo }}$ & $\mathrm{Cd}$ & $\mathrm{Co}$ & $\mathrm{Cr}$ & $\mathrm{Cu}$ & $\mathrm{Pb}$ & $\mathrm{Zn}$ & $\mathrm{As}$ & $\mathrm{Ni}$ & $\mathrm{Mn}$ & Reference \\
\hline Bayan Obo & 5.21 & 0.98 & 1.35 & 0.90 & 3.05 & 1.99 & 0.36 & 0.31 & 2.30 & This study \\
Hangzhou & 3.14 & 0.10 & -1.10 & 1.70 & 2.42 & 1.51 & & -0.88 & -0.98 & Zhang and Wang, 2009 \\
Urumqi & 0.80 & -0.30 & -0.10 & 0.40 & 0.30 & 0.50 & & 0.00 & 0.00 & Wei et al., 2009 \\
Shanghai & 2.65 & & 0.50 & 2.19 & 2.94 & 2.54 & & 0.84 & & Shi et al., 2008
\end{tabular}


EFs were used to identify whether the heavy metals originated from non-crustal sources or crustal sources. The EF values for nine studied metals in road dust of Bayan Obo are listed in Table 6. The average values of $\mathrm{EF}$ for $\mathrm{Cd}, \mathrm{Pb}$, and $\mathrm{Mn}$ were greater than 10 , indicating that enrichment of these three metals, particularly $\mathrm{Cd}$, was caused by anthropogenic sources, whereas the average values of $\mathrm{EF}$ for $\mathrm{Cr}, \mathrm{Cu}, \mathrm{Co}$, $\mathrm{As}$ and $\mathrm{Ni}$ ranged between 2.6-5.5, implying mixed influence of both crustal and non-crustal sources. Although the EF value for Zn (8.82) was slightly lower than the threshold value $(=10)$, it is reasonable that anthropogenic sources heavily contributed to $\mathrm{Zn}$ contamination.

Table 6 The average EFs values of heavy metals in road dust collected in Bayan Obo (April 2014)

\begin{tabular}{llllllllll}
\hline & $\mathrm{Cd}$ & $\mathrm{Cr}$ & $\mathrm{Cu}$ & $\mathrm{Pb}$ & $\mathrm{Zn}$ & $\mathrm{Co}$ & $\mathrm{As}$ & $\mathrm{Ni}$ & $\mathrm{Mn}$ \\
\hline $\mathrm{EF}$ & 81.37 & 5.31 & 3.74 & 19.51 & 8.82 & 3.98 & 2.57 & 2.53 & 11.0 \\
\hline
\end{tabular}

\subsection{Health risk assessment results}

\subsubsection{Non-carcinogenic risk assessment}

The HQ and $\mathrm{HI}$ for $\mathrm{Cr}, \mathrm{Ni}, \mathrm{Pb}, \mathrm{Cd}, \mathrm{Cu}, \mathrm{Mn}, \mathrm{As}, \mathrm{Co}$ and $\mathrm{Zn}$ in road dust samples of Bayan Obo residential areas were calculated (Table 7). The integrated HI values were 1.89 for children and 0.23 for adults living in Bayan Obo region, indicating children are likely to experience significantly higher non-cancer risks.

Among three different exposure pathways, the $\mathrm{HQ}_{\text {ing }}$ values were the highest and contributed the most to HIs for both children and adults, indicating that ingestion of road dust appears to be the most threatening exposure way to human health in Bayan Obo (Figure 4). The inhalation of road dust had the lowest contribution to health risks for children and the $\mathrm{HQ}_{\text {inh }}$ values were 2-4 orders of magnitude lower compared with the other two pathways for children, indicating that the non-cancer risks posed by the inhalation of resuspended road dust might be negligible compared with ingestion and dermal contact. Similar results were obtained by previous studies (Ferreira-Baptista and De Miguel, 2005; Zheng et al., 2010a).

Table 7 HIs for each non-carcinogenic metal in road dust collected in Bayan Obo (April 2014)

\begin{tabular}{lrrrrrr}
\hline & C $(95 \% \mathrm{UCL})$ & Oral RfD & Inhal RfD & Dermal RfD & \multicolumn{2}{c}{ HQ ingestion } \\
\cline { 5 - 7 } $\mathrm{Cd}$ & 2.59 & $1.00 \mathrm{E}-03$ & $1.00 \mathrm{E}-03$ & $5.00 \mathrm{E}-05$ & $1.82 \mathrm{E}-03$ & $1.70 \mathrm{E}-02$ \\
$\mathrm{Cr}$ & 157.87 & $3.00 \mathrm{E}-03$ & $2.86 \mathrm{E}-05$ & $6.00 \mathrm{E}-05$ & $3.71 \mathrm{E}-02$ & $3.46 \mathrm{E}-01$ \\
$\mathrm{Cu}$ & 39.33 & $4.00 \mathrm{E}-02$ & $4.02 \mathrm{E}-02$ & $1.20 \mathrm{E}-02$ & $6.93 \mathrm{E}-04$ & $6.47 \mathrm{E}-03$ \\
$\mathrm{~Pb}$ & 225.19 & $3.50 \mathrm{E}-03$ & $3.52 \mathrm{E}-03$ & $5.25 \mathrm{E}-04$ & $4.53 \mathrm{E}-02$ & $4.23 \mathrm{E}-01$ \\
$\mathrm{Zn}$ & 350.18 & $3.00 \mathrm{E}-01$ & $3.00 \mathrm{E}-01$ & $6.00 \mathrm{E}-02$ & $8.22 \mathrm{E}-04$ & $7.68 \mathrm{E}-03$ \\
$\mathrm{Ni}$ & 33.63 & $2.00 \mathrm{E}-02$ & $2.06 \mathrm{E}-02$ & $5.40 \mathrm{E}-03$ & $1.18 \mathrm{E}-03$ & $1.11 \mathrm{E}-02$ \\
$\mathrm{Co}$ & 28.88 & $2.00 \mathrm{E}-02$ & $5.71 \mathrm{E}-06$ & $1.60 \mathrm{E}-02$ & $1.02 \mathrm{E}-03$ & $9.49 \mathrm{E}-03$ \\
$\mathrm{As}$ & 13.13 & $3.00 \mathrm{E}-04$ & $3.01 \mathrm{E}-04$ & $1.23 \mathrm{E}-04$ & $3.08 \mathrm{E}-02$ & $2.88 \mathrm{E}-01$ \\
$\mathrm{Mn}$ & 3991.06 & $4.60 \mathrm{E}-02$ & $1.43 \mathrm{E}-05$ & $1.84 \mathrm{E}-03$ & $6.11 \mathrm{E}-02$ & $5.70 \mathrm{E}-01$ \\
$\mathrm{Sum}$ & & & & & $1.80 \mathrm{E}-01$ & $1.68 \mathrm{E}+00$ \\
\hline \hline
\end{tabular}




\begin{tabular}{lcccccc}
\hline \hline & \multicolumn{2}{c}{ HQ inhalation } & \multicolumn{2}{c}{ HQ dermal } & \multicolumn{2}{c}{ HI } \\
\cline { 2 - 7 } & Adult & Children & Adult & Children & Adult & Children \\
\hline $\mathrm{Cd}$ & $2.81 \mathrm{E}-07$ & $4.98 \mathrm{E}-07$ & $1.52 \mathrm{E}-04$ & $9.98 \mathrm{E}-04$ & $1.98 \mathrm{E}-03$ & $1.80 \mathrm{E}-02$ \\
$\mathrm{Cr}$ & $5.71 \mathrm{E}-04$ & $1.01 \mathrm{E}-03$ & $7.39 \mathrm{E}-03$ & $4.84 \mathrm{E}-02$ & $4.50 \mathrm{E}-02$ & $3.95 \mathrm{E}-01$ \\
$\mathrm{Cu}$ & $1.01 \mathrm{E}-07$ & $1.80 \mathrm{E}-07$ & $1.00 \mathrm{E}-05$ & $6.55 \mathrm{E}-05$ & $7.03 \mathrm{E}-04$ & $6.53 \mathrm{E}-03$ \\
$\mathrm{~Pb}$ & $6.98 \mathrm{E}-06$ & $1.24 \mathrm{E}-05$ & $1.27 \mathrm{E}-03$ & $8.32 \mathrm{E}-03$ & $4.66 \mathrm{E}-02$ & $4.31 \mathrm{E}-01$ \\
$\mathrm{Zn}$ & $1.34 \mathrm{E}-07$ & $2.38 \mathrm{E}-07$ & $1.82 \mathrm{E}-05$ & $1.19 \mathrm{E}-04$ & $8.41 \mathrm{E}-04$ & $7.79 \mathrm{E}-03$ \\
$\mathrm{Ni}$ & $1.65 \mathrm{E}-07$ & $2.93 \mathrm{E}-07$ & $1.71 \mathrm{E}-05$ & $1.12 \mathrm{E}-04$ & $1.20 \mathrm{E}-03$ & $1.12 \mathrm{E}-02$ \\
$\mathrm{Co}$ & $5.23 \mathrm{E}-04$ & $9.27 \mathrm{E}-04$ & $5.06 \mathrm{E}-06$ & $3.32 \mathrm{E}-05$ & $1.55 \mathrm{E}-03$ & $1.05 \mathrm{E}-02$ \\
$\mathrm{As}$ & $4.57 \mathrm{E}-06$ & $8.11 \mathrm{E}-06$ & $9.00 \mathrm{E}-03$ & $5.90 \mathrm{E}-02$ & $3.98 \mathrm{E}-02$ & $3.47 \mathrm{E}-01$ \\
$\mathrm{Mn}$ & $2.89 \mathrm{E}-02$ & $5.13 \mathrm{E}-02$ & $6.10 \mathrm{E}-03$ & $3.99 \mathrm{E}-02$ & $9.61 \mathrm{E}-02$ & $6.62 \mathrm{E}-01$ \\
$\mathrm{Sum}$ & $3.00 \mathrm{E}-02$ & $5.32 \mathrm{E}-02$ & $2.40 \mathrm{E}-02$ & $1.57 \mathrm{E}-01$ & $2.34 \mathrm{E}-01$ & $1.89 \mathrm{E}+00$ \\
\hline
\end{tabular}

Additionally, children were found to experience higher health risks through ingestion compared with adults. The values of $\mathrm{HQ}_{\text {ing }}$ for children were 9.33 times higher than those for adults and accounted for larger proportions (88.9\% for children, $76.9 \%$ for adults) in integrated HI values. This result may be partially attributed to the special behavior patterns of children, particularly frequent hand-to-mouth contact.

The HIs for all studied metals were ranked in the order: $\mathrm{Mn}>\mathrm{Pb}>\mathrm{Cr}>\mathrm{As}>\mathrm{Cd}>\mathrm{Co}>$ $\mathrm{Ni}>\mathrm{Zn}>\mathrm{Cu}$ for adults, and $\mathrm{Mn}>\mathrm{Pb}>\mathrm{Cr}>\mathrm{As}>\mathrm{Cd}>\mathrm{Ni}>\mathrm{Co}>\mathrm{Zn}>\mathrm{Cu}$ for children (Table 7 and Figure 5). $\mathrm{Mn}, \mathrm{Cr}, \mathrm{Pb}$, and As were the main contributors to health risks posed by road dust metals exposure for both children and adults, and $\mathrm{Cu}$ had the smaller contribution. The $\mathrm{HQ}_{\text {inh }}$ of $\mathrm{Mn}$ and the $\mathrm{HQ}_{\text {derm }}$ of $\mathrm{Cr}$ and As were 2-5 orders of magnitude higher than those of other metals for both children and adults, suggesting that exposure to $\mathrm{Cr}$ and As via dermal contact, and for Mn through inhalation, may produce the most serious health effects.

The HI values for all metals tested in this study were within the safe level $(=1)$, suggesting minimal non-carcinogenic risk to children and adults from exposure to road dust metals. However, the integrated $\mathrm{HI}$ for children $(\mathrm{HI}=1.89)$ slightly exceeded the safe level $(=1)$, indicating that the potential health risk to children should be addressed and studied in more detail.
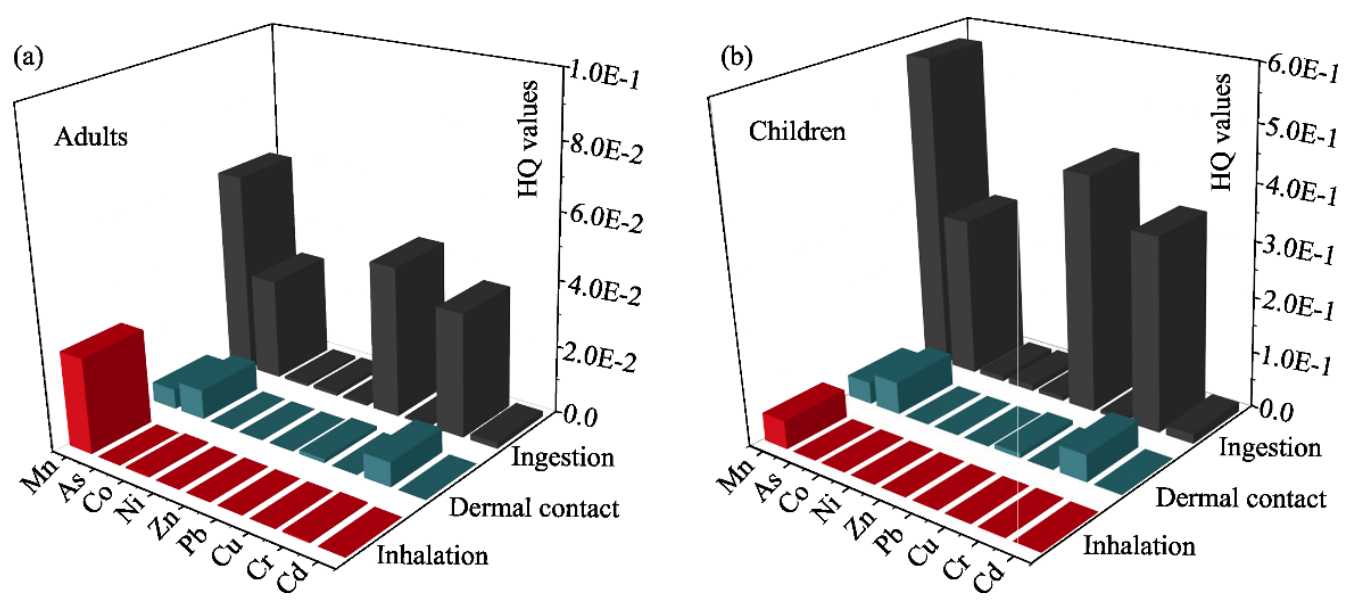

Figure 5 The HQs of each heavy metal in road dust in Bayan Obo for adults (a) and children (b) (April 2014) 


\subsubsection{Carcinogenic risk assessment}

The cancer risks according to inhalation exposure to $\mathrm{Cd}, \mathrm{Cr}, \mathrm{Ni}, \mathrm{Co}$, and As are presented in Table 8. Results showed that the overall risk of cancer decreased in the order $\mathrm{Cr}>\mathrm{Co}>\mathrm{As}>$ $\mathrm{Ni}>\mathrm{Cd}$. The leading heavy metal was $\mathrm{Cr}$ for which cancer risks were 1-3 orders of magnitude higher than those for other metals. Overall, cancer risk values for all heavy metals in this study were within the acceptable range, implying negligible carcinogenic risk.

Table 8 Cancer risks for each carcinogenic metal in road dust collected in Bayan Obo (April 2014)

\begin{tabular}{cccccc}
\hline & $\mathrm{Cd}$ & $\mathrm{Cr}$ & $\mathrm{Ni}$ & $\mathrm{Co}$ & $\mathrm{As}$ \\
\hline Inhal SF & $6.30 \mathrm{E}+00$ & $4.20 \mathrm{E}+01$ & $8.40 \mathrm{E}-01$ & $9.80 \mathrm{E}+00$ & $1.51 \mathrm{E}+01$ \\
R & $8.37 \mathrm{E}-10$ & $3.40 \mathrm{E}-07$ & $1.45 \mathrm{E}-09$ & $1.45 \mathrm{E}-08$ & $1.02 \mathrm{E}-08$ \\
\hline
\end{tabular}

\section{Conclusions}

A total of 23 road dust samples were collected from Bayan Obo Mining Region in the spring of 2014. The concentration and spatial distribution patterns of 9 potentially toxic heavy metal elements ( $\mathrm{As}, \mathrm{Cd}, \mathrm{Co}, \mathrm{Cr}, \mathrm{Pb}, \mathrm{Cu}, \mathrm{Zn}, \mathrm{Mn}$, and $\mathrm{Ni}$ ) in road dust were analyzed. Contamination levels were evaluated using the geoaccumulation index and the enrichment factor. Human health risks for each heavy metal element were assessed using a human exposure model.

Results showed: (1) Concentrations of $\mathrm{Cd}, \mathrm{Co}, \mathrm{Zn}, \mathrm{Pb}, \mathrm{Ni}, \mathrm{As}, \mathrm{Cu}, \mathrm{Mn}$, and $\mathrm{Cr}$ were significantly higher compared with background values. (2)The spatial distribution of $\mathrm{Cd}, \mathrm{Co}$, $\mathrm{Zn}, \mathrm{Pb}, \mathrm{Ni}, \mathrm{Cu}, \mathrm{Mn}$, and $\mathrm{Cr}$ were all in accordance with the locations of industrial areas and the predominant wind direction, indicating that these eight metals likely originated from industrial sources. The spatial distribution of As showed a different pattern and was instead primarily associated with domestic pollution sources, including firework use and coal combustion. (3) Contamination assessments showed that the road dust in Bayan Obo was contaminated by all investigated metals to varying extents. $\mathrm{Cd}$, with an average $\mathrm{I}_{\text {geo }}$ value of 5.21, presented the highest pollution risk. Moreover, the road dust was categorized as heavily polluted by $\mathrm{Mn}$ and $\mathrm{Pb}$ and moderately polluted by $\mathrm{Zn}$ and $\mathrm{Cr}$, whereas $\mathrm{Cu}, \mathrm{As}$, $\mathrm{Ni}$ and $\mathrm{Co}$ in the dust were rated as "moderately polluted" to "polluted" based on average I geo values. (4) EF values indicated that accumulation of $\mathrm{Cd}, \mathrm{Pb}$, and $\mathrm{Mn}$ in road dust was caused mainly by human activities, whereas the enrichment of other metals derived from a combination of crustal and anthropogenic sources. The EF value of $\mathrm{Zn}$ (8.82) was close to the threshold value 10, implying a greater influence from human activities. (5) The health risks analysis showed that ingestion was the dominant exposure pathway for both children and adults. The sum of $\mathrm{HI}$ values for $\mathrm{Mn}, \mathrm{Cr}, \mathrm{Pb}$, and As accounted for nearly $98 \%$ of the integrated $\mathrm{HI}$ values, indicating that these four metals were the greatest contributors to non-cancer risks. (6) Among the 5 carcinogenic metals, $\mathrm{Cr}$ was the leading contributor to cancer risks, followed by $\mathrm{Co}$, As, $\mathrm{Ni}$, and Cd. (7) Although both non-carcinogenic and carcinogenic risk for each metal fell within acceptable values, children were more susceptible than adults and experienced higher non-carcinogenic risk from exposure to metals in road dust. The risks to children living in the mining region of Bayan Obo from exposure to mining-related activities should receive greater attention. 


\section{References}

Apeagyei E, Bank M S, Spengler J D, 2011. Distribution of heavy metals in road dust along an urban-rural gradient in Massachusetts. Atmospheric Environment, 45(13): 2310-2323.

Cheng X, Taylor R N, Li W et al., 2012. Comparison of fluorite geochemistry from REE deposits in the Panxi region and Bayan Obo, China. Journal of Asian Earth Sciences, 57: 76-89.

Cook A G, Weinstein P, Centeno J A, 2005. Health effects of natural dust. Biological Trace Element Research, 103(1): 1-15.

Csavina J, Field J, Taylor M P et al., 2012. A review on the importance of metals and metalloids in atmospheric dust and aerosol from mining operations. Science of the Total Environment, 433: 58-73.

Drew L J, Meng Q, Sun W, 1990. The Bayan Obo iron-rare-earth-niobium deposits, Inner Mongolia. China. Lithos, 26(1): 43-65.

Ferreira-Baptista L, De Miguel E, 2005. Geochemistry and risk assessment of street dust in Luanda, Angola: A tropical urban environment. Atmospheric Environment, 39(25): 4501-4512.

$\mathrm{Fu} \mathrm{K}$, Su B, He D et al., 2012. Pollution assessment of heavy metals along the Mekong River and dam effects. Journal of Geographical Sciences, 22(5): 874-884.

Gao H, Wang X, Zhang Q et al., 2007. Characteristics of soil background value in Hetao area, Inner Mongolia. Geology and Resources, 16(3): 209-212. (in Chinese)

Guo W, Fu R, Zhao R et al., 2011. Distribution Characteristic and Assessment of Soil Heavy Metal Pollution in the Iron Mining of Baotou in Inner Mongolia. Chinese Journal of Environmental Science, 32(10): 3099-3105. (in Chinese)

IARC (International Agency for Research on Cancer), 2014. Agents Classified by the IARC Monographs, Vol. 1109.

Liu E, Yan T, Birch G et al., 2014. Pollution and health risk of potentially toxic metals in urban road dust in Nanjing, a mega-city of China. Science of the Total Environment, 476: 522-531.

Lu X, Li L Y, Wang L et al., 2009. Contamination assessment of mercury and arsenic in roadway dust from Baoji, China. Atmospheric Environment, 43(15): 2489-2496.

Lu X, Wang L, Lei K et al., 2009. Contamination assessment of copper, lead, zinc, manganese and nickel in street dust of Baoji, NW China, Journal of Hazardous Materials, 161: 1058-1062.

Moreno T, Karanasiou A, Amato F et al., 2013. Daily and hourly sourcing of metallic and mineral dust in urban air contaminated by traffic and coal-burning emissions. Atmospheric Environment, 68: 33-44.

Muller G, 1969. Index of geo-accumulation in sediments of the Rhine River. Geo Journal, 2(3): 108-118

Risk Assessment Guidance for Superfund .Volume I: Human Health Evaluation Manual, Part E: Supplemental Guidance for Dermal Risk Assessment. EPA/540/R/99/005, OSWER 9285.7-02EP PB99-963312, 2004. Office of Superfund Remediation and Technology Innovation, U.S. Environmental Protection Agency Washington, D.C.

Risk Assessment Guidance for Superfund Volume I Human Health Evaluation Manual (Part A) EPA/540/1-89/002, 1989. Office of Emergency and Remedial Response, U.S. Environmental Protection Agency Washington, D.C.

Shi G, Chen Z, Xu S et al., 2008. Potentially toxic metal contamination of urban soils and roadside dust in Shanghai. China. Environmental Pollution, 156: 251-260.

Si W, Liu J, Cai L et al., 2015. Health risks of metals in contaminated farmland soils and spring wheat irrigated with Yellow River water in Baotou, China. Bulletin of Environmental Contamination and Toxicology, 94(2): $214-219$.

Sun C, Bi C, Chen Z et al., 2010. Assessment on environmental quality of heavy metals in agricultural soils of Chongming Island, Shanghai City. Journal of Geographical Sciences, 20(1): 135-147.

Supplemental Guidance for Developing Soil Screening Level for Superfund Sites. OSWER 9355.4-24, 2001. Office of Solid Waste and Emergency Response, Environmental Protection Agency Washington, D.C.

Supplemental Guidance to RAGS: Calculating the Concentration Term. PB92-963373, 1992. Office of Solid Waste and Emergency Response, Environmental Protection Agency Washington, D.C.

Valko M, Rhodes C J, Moncol J et al., 2006. Free radicals, metals and antioxidants in oxidative stress-induced cancer. Chemico-biological Interactions, 160(1): 1-40.

Wang L, Guo Z, Xiao X et al., 2008. Heavy metal pollution of soils and vegetables in the midstream and downstream of the Xiangjiang River, Hunan Province. Journal of Geographical Sciences, 18(3): 353-362.

Wang L, Liang T, Zhang Q et al., 2014. Rare earth element components in atmospheric particulates in the Bayan Obo mine region. Environmental Research, 131: 64-70. 
Wei B, Jiang F, Li W et al., 2009. Spatial distribution and contamination assessment of heavy metals in urban road dusts from Urumqi, NW China. Microchemical Journal, 93: 147-152.

$\mathrm{Wu} \mathrm{C}, 2008$. Bayan Obo Controversy: Carbonatites versus Iron Oxide - $\mathrm{Cu}-\mathrm{Au}-(\mathrm{REE}-\mathrm{U})$. Resource Geology, 58(4): 348-354. (in Chinese)

$\mathrm{Xu}$ S, Tao S, 2004. Coregionalization analysis of heavy metals in the surface soil of Inner Mongolia. Science of the Total Environment, 320: 73-87.

Zhang J, Zheng C, Liu J et al., 2002. Advance of pollution and retention of arsenic in coal combustion. Coal Conversion, 25(2): 23-28. (in Chinese)

Zhang M, Wang H, 2009. Concentrations and chemical forms of potentially toxic metals in road-deposited sediments from different zones of Hangzhou, China. Journal of Environmental Sciences, 21: 625-631.

Zheng G, Yue L, Li Z et al., 2006. Assessment on heavy metals pollution of agricultural soil in Guanzhong district. Journal of Geographical Sciences, 16(1): 105-113.

Zheng N, Liu J, Wang Q et al., 2010a. Health risk assessment of heavy metal exposure to street dust in the zinc smelting district, northeast of China. Science of the Total Environment, 408(4): 726-733.

Zheng N, Liu J, Wang Q et al., 2010b. Heavy metals exposure of children from stairway and sidewalk dust in the smelting district, northeast of China. Atmospheric Environment, 44(27): 3239-3245. 